\title{
Influence of Plant Competition and Pod Position on Seed Yield Components and Protein Content in Beans $^{1}$
}

\author{
Augusto Tulmann Neto, F. K. S. Koo, and J. Cuevas-Ruíz ${ }^{2}$
}

\section{ABSTRACT}

The influence of plant competition and pod position on yield components and protein content was studied in beans (Phaseolus vulgaris L.). Plants grown under conditions of relaxed competition were found to increase yield, number of pods/plant, and weight of 100 seeds. However, number of seeds/pod and protein percentage content were not affected by competition. In the study of pod position effect, it was observed that seed weight was affected by pod position somewhat differently in two bean varieties, although both had the lighter seeds in the upper pods. However, the protein content was independent of pod position on the plant. Variety Carioca had heavier seed than variety Jamapa, but the former had lower protein content than the latter.

\section{INTRODUCTION}

In field experiments, performance measurement for space-planted individual plants may be desired at times, even though experimental data are often taken on a plot basis. When individual plants are to be measured, a full and uniform stand becomes highly desirable. But perfect stand may not always be obtained due to failure in germination and emergence or damage caused by insects and diseases.

Less competitive plants generally yield more than plants under high competition. Paterniani et al. ${ }^{3}$ reported that corn plants without competition yielded $25.6 \%$ more than plants with full competition.

The purpose of the first part of this investigation was to observe the effect of plant competition on yield components and protein content in beans.

The second part of the investigation was concerned with the effect of position on the plant of bean seed of two varieties on average weight and protein content.

' Manuscript submitted to Editorial Board April 12, 1977.

${ }^{2}$ Scientist and Head, Radiation Genetics Section, Centro de Energía Nuclear na Agricultura, Brazil; Senior Scientist and Head, Tropical Agro-Sciences Division, Center for Energy and Environment Research; and Scientist, Tropical Agro-Sciences Division, Center for Energy and Environment Research, Mayagüez Campus, University of Puerto Rico, Mayagüez, P.R. The senior author wishes to express his gratitude to the International Atomic Energy Agency for the fellowship he held during the course of this investigation.

${ }^{3}$ Paterniani, E., Miranda Filho, J. B., and Zinsly, J. R., 1971. Efeito da competição entre as plantas de milho na productividade. Relatório Cientifico do Instituto de Genetica, 223-8. 


\section{MATERIALS AND METHODS}

For the competition effect study, bean vareity Dark Red Kidney (bush type) was planted in the field in randomized blocks with three replications. Each experimental row was guarded with two border rows, one on each side. The rows were spaced $40 \mathrm{~cm}$ apart and the plants in the row were $10 \mathrm{~cm}$ apart. The layout of the experimental plots was as follows: a) Full competition: the assay plant was guarded by two plants on each side; b) half competition: the assay plant was guarded by two plants on one side and no immediate plant on the other side (in this case $20 \mathrm{~cm}$ space between the assay plant and the guard plant); c) partial competition: the assay plant was guarded by only one plant on one side and no plant immediately on the other side; d) no competition: the assay plant had no guard plant immediately on either side.

After harvesting, the plants were oven dried at $106^{\circ} \mathrm{F}$ for 2 days; the pods were then picked from individual plants, and yield/plant, number of pods/plant, number of seeds/pod, weight of 100 seeds, and protein content were determined. All weight values are presented on the basis of $15 \%$ moisture content. Protein content was determined in five replicates by the micro-Kjeldahl method (A.O.A.C.). The samples were first ground in a mill and passed through a 40-mesh sieve. Samples weighing $50 \mathrm{mg}$ (adjusted to 15\% moisture content) were analyzed. The protein content was calculated by multiplying $\mathrm{N} \%$ by 6.25 .

For the study of pod position effect on seed weight and protein content, two bean varieties, Carioca (vine type) and Jamapa (bush type) were planted $10 \mathrm{~cm}$ apart and $60 \mathrm{~cm}$ between rows in the field in randomized blocks with 5 replications, with 20 plants/row for each variety. Because of severe disease infection, only the competitive plants in three replications were individually harvested. After oven drying, pods of each plant were grouped according to their position on the plant into upper, central, and lower groups, with two to four pods in each group from each plant. The pods from each position group of a variety in each replication were bulked and threshed. The total seed weight of each group was first determined and the average seed weight at $15 \%$ moisture was obtained by dividing the total weight by the number of seeds in the group. Protein content was determined by the microKjeldahl method.

\section{RESULTS AND DISCUSSION}

\section{COMPETITION EFFECT STUDY}

Table 1 shows results of the competition effect study. The plants with partial or no competition yielded significantly more than the ones with 
full or half competition. Furthermore, number of pods/plant differed significantly for all treatments. The number of pods/plant increased with decreasing competition. However, no difference was observed among the treatments in number of seeds/pod, indicating lack of competition effect.

The weight of 100 seeds shows that the plants with partial and no competitions were significantly heavier than those with full and half competition.

There was no significant difference in percentage protein content among treatments, indicating that competition had no effect on this characteristic.

For performing the analysis of variance for the protein content (\%), the actual values were first transformed into $\sin ^{2} \theta$.

TABLE 1. - Average yield per plant and some other response parameters of bean variety Dark Red Kidney to competition

\begin{tabular}{lccccc}
\hline \multicolumn{1}{c}{ Treatment } & Yield' & Pods/plant & Seeds/pod & $\begin{array}{c}\text { Weight of } \\
100 \text { seeds }\end{array}$ & $\begin{array}{c}\text { Protein } \\
\text { content }\end{array}$ \\
\hline Full competition & $g$ & No & No. & $g$ & $\%$ \\
Half competition & $4.19 \mathrm{~b}^{2}$ & $4.90 \mathrm{~d}$ & $2.25 \mathrm{a}$ & $37.2 \mathrm{~b}$ & $20.8 \mathrm{a}$ \\
Partial competition & $5.48 \mathrm{~b}$ & $6.30 \mathrm{c}$ & $2.43 \mathrm{a}$ & $36.2 \mathrm{~b}$ & $20.1 \mathrm{a}$ \\
No competition & $9.18 \mathrm{a}$ & $7.77 \mathrm{~b}$ & $2.77 \mathrm{a}$ & $42.1 \mathrm{a}$ & $20.3 \mathrm{a}$ \\
\hline
\end{tabular}

At $15 \%$ moisture.

${ }^{2}$ Mean values in columns followed by the same letter do not differ significantly at the $5 \%$ level.

\section{POD POSITION EFFECT STUDY}

Table 2 shows the average seed weight (adjusted to $15 \%$ moisture content) for each of the three position groups in the two varieties. The data were analyzed as a randomized block trial as well as a factorial experiment. In Carioca there was no difference between the average seed weight for the lower and central pods, but the upper pods had significantly lighter seeds. For variety Jamapa, the seed at three pod positions were different in weight. The lower pods had the heaviest seeds, the central pods were intermediate, and the upper pods were lightest. The analysis also showed that the difference in seed weight between the varieties was significant, Carioca being heavier than Jamapa. However, no difference was indicated for variety $\times$ pod. position interaction.

Statistically significant difference in protein content was indicated only between the varieties, Jamapa having a higher content (table 2).

These findings indicate that the plants grown under conditions where competition is relaxed tend to increase in yield, number of pods/plant 
and weight of 100 seeds. This suggests that when dealing with the measurement of these characteristics, the competition effect must be taken into consideration.

The protein content was the same for the plants grown under different degrees of competition. Even in the extreme case of total lack of competition, there was no increase in protein content. Therefore, no bias risk should exist in taking measurement of protein content without considering competition.

In the study of pod position effect on average seed weight, it was found that pod position influenced seed weight somewhat differently in Carioca and Jamapa, although both varieties had the lighter seeds in the upper pods.

TABLE 2.-Average seed weight and protein content of three pod position groups in two bean varieties

\begin{tabular}{ccc}
\hline Variety and pod position & Seed weight ${ }^{\prime}$ & Protein content \\
\hline Carioca & $g$ & $\%$ \\
lower & $0.236 \mathrm{a}^{2}$ & $24.0 \mathrm{a}$ \\
central & $.237 \mathrm{a}$ & $23.3 \mathrm{a}$ \\
upper & $.196 \mathrm{~b}$ & $24.4 \mathrm{a}$ \\
Jamapa & $.192 \mathrm{a}$ & $26.4 \mathrm{a}$ \\
lower & $.181 \mathrm{~b}$ & $26.5 \mathrm{a}$ \\
central & $.152 \mathrm{c}$ & $26.4 \mathrm{a}$ \\
upper & & \\
\hline
\end{tabular}

' At $15 \%$ moisture

${ }^{2}$ Mean values within each variety followed by the same letter do not differ significantly at the $5 \%$ level.

Also the fact that variety Jamapa, with lower seed weight and higher protein content when compared with Carioca, is in line with the finding of Rutger ${ }^{4}$ with several bean varieties, where a negative correlation between seed weight and protein content was observed.

In Carioca and Jamapa, no difference in protein content was observed among different pod positions. Apparently, the protein content of bean seed is independent of position on the plant, and therefore, the seed from the whole plant can be bulked for a reliable protein determination.

\section{RESUMEN}

La influencia de la competencia entre plantas y la posición de las vainas sobre los componentes de rendimiento y contenido en proteína se estudiaron en variedades de habichuelas (Phaseolus vulgaris L.).

Para estudiar la competencia entre plantas, se sembró la variedad Dark Red Kidney en hileras a $40 \mathrm{~cm}$. de separación y a $10 \mathrm{~cm}$. entre plantas en la hilera. Se usó un diseño experimental de bloques distribuidos al azar, con los tratamientos repetidos tres veces.

${ }^{4}$ Rutger, J. N., 1970. Variation in protein content and its relation to other characters in beans (Phaseolus vulgaris L.). The Tenth Dry Bean Res. Conf., 59-69. 
Los tratamientos fueron: a) competencia total (dos plantas sembradas a cada lado de la planta experimental); b) media competencia (dos plantas en un lado y una en el otro); c) competencia parcial (una planta en un solo lado), y d) sin competencia (sin ninguna planta en ambos lados).

Para estudiar el efecto de la posición de las vainas sobre el peso y el contenido en proteína de las semillas, las variedades Carioca (trepadora) y Jamapa (arbustiva) se sembraron a $10 \mathrm{~cm}$. de separación en hileras a $60 \mathrm{~cm}$. Los tratamientos se repitieron cinco veces.

Las plantas con menos competencia arrojaron aumentos en rendimiento, en número de vainas por planta y en el peso de 100 semillas. Sin embargo, la competencia no afectó el número de semillas por vaina ni el porcentaje en proteína. La posición de las vainas en la planta afectó de manera diferente el peso de las semillas en cada variedad, a pesar de que en ambas las semillas eran más livianas en las vainas superiores. El contenido en proteína no varió por efecto de la posición de las vainas. La variedad Carioca produjo semillas más pesadas que la variedad Jamapa, pero su contenido en proteína fue más bajo. 